\title{
Variation in genetic and environmental effects of beta-conglycinin (7S) and glycinin (11S) protein fractions in conventional and GM soybean cultivars grown in Southern Brazil
}

\section{Efeito de genética e meio ambiente nos teores de frações proteicas beta-conglicinina (7S) e glicinina (11S) em cultivares de soja convencionais e transgênicas cultivadas no sul do Brasil}

\author{
Olívio Fernandes Galão ${ }^{1 *}$; Arlindo Inês Teixeira ${ }^{2}$; Maurílio Alves Moreira ${ }^{3}$; \\ Mercedes Concórdia Carrão-Panizzi ${ }^{4}$; Jesui Vergílio Visentainer ${ }^{5}$
}

\begin{abstract}
The objective of this study was to evaluate the effects of genetic and environmental variation on levels of beta-conglycinin and glycinin in commercial soybean cultivars, which were sown in showcases at Embrapa Soja, Londrina, simultaneously in Ponta Grossa, south Brazil. The concentration of protein fractions was determined by densitometry after electrophoresis in 20 cultivars, 14 conventional and 6 transgenic. We observed a significant variation as the ratio of beta-conglycinin (7S) and glycinin (11S) between the cultivars analyzed. Most 11S/7S ratios (2.21) was observed in the BRS 184, Ponta Grossa and lowest (1.31) in the BRS 233, Londrina. On average, transgenic varieties of Ponta Grossa were higher than in Londrina for both, taking into account the amount of protein fractions.

Key words: Soybean, glycinin and beta-conglycinin, protein fractions
\end{abstract}

\section{Resumo}

O objetivo deste estudo foi avaliar os efeitos de genética e meio ambiente na concentração de beta-conglicinina e glicinina em variedades de soja comercial e que foram cultivadas em fazendas experimentais da Embrapa-soja de Londrina e de Ponta Grossa, no sul do Brasil. A concentração das frações proteicas foi determinada por densitometria após análise por eletroforese em 20 cultivares, sendo 14 convencionais e 6 variedades transgênicas. Foram observadas diferenças significativas na razão de beta-conglicinina (7S) e glicinina (11S) nestas variedades cultivadas. A maior razão 11/7S foi observada na variedade BRS 184 de Ponta Grossa e a menor $(1,31)$ na variedade BRS 233 de Londrina. Em média as variedades transgênicas de Ponta Grossa apresentaram maiores relações que aquelas de Londrina, tendo em conta as quantidades de frações proteicas.

Palavras-chave: Soja, frações proteicas, glicinina e beta-conglicinina

\footnotetext{
${ }^{1}$ Prof. Pesquisador, Universidade Estadual de Londrina, UEL, Rod. Celso Garcia Cid, km 380, Londrina, PR. E-mail: galao@uel.br

2 Prof. Pesquisador, Instituto de Biotecnologia Aplicada à Agropecuária, BIOAGRO, Universidade Federal de Viçosa, UFV, Campus Universitário, CEP 36570-000, Viçosa, MG. E-mail: aiteixeira@yahoo.com

${ }^{3}$ Prof. Pesquisador, Dept ${ }^{\circ}$ de Bioquímica e Biologia Molecular, UFV, Viçosa, MG. E-mail: moreira@ufv .br

${ }^{4}$ Pesquisadora, Embrapa Wheat, Rod. BR-285, Km. 294, CEP 99001-970, Passo Fundo. RS. E-mail mercedes@cnpt.embrapa.br

${ }^{5}$ Prof. Pesquisador, Universidade Estadual de Maringá, UEM, Maringá, PR. E-mail: jvvisentainer@uem.br

${ }^{*}$ Author for corespondence
} 


\section{Introduction}

Brazil is the second largest producer and exporter of soybeans in the world (AGRIANUAL, 2010), especially in grain, oil and protein. The added value of the product depends on the oil content and grain protein. The amount of protein corresponds to $40 \%$ and oil 20\% (PIPOLO, 2002). About $70 \%$ of the protein corresponding to glycinin (11S) and $\beta$-conglycinin (7S) (CARRÃO-PANIZZI, $2008)$. The $7 \mathrm{~S}$ globunin, is a trimeric glycoprotein consisting of three types of subunits $\left(\alpha, \alpha^{\prime}\right.$ and $\left.\beta\right)$ and the $11 \mathrm{~S}$ fraction has subunits $\mathrm{A} 1 \mathrm{aB} 2, \mathrm{~A} 1 \mathrm{bB} 1 \mathrm{~b}$, A2B1a, A3B4 and A5A4B3 (NIELSEN et al., 1995). According to Ogawa et al. (1989), Kitamura (1995) and Moraes (2006) cultivars that have reduced levels of protein fractions $7 \mathrm{~S}$, compensate this loss with increased synthesis of $11 \mathrm{~S}$ protein fractions, which keeps unchanged the total protein content. The 7S protein is not suitable for production of tofu as brittle product form, however, the higher the $11 \mathrm{~S} / 7 \mathrm{~S}$ ratios, the better the quality of the gel. The 7S fraction was reported by Bittercourt et al. (2007) as capable of producing allergic reactions in mice. The 11S fraction is more suitable for tofu, due to its higher content of sulfur amino acids dominated by -S-S- bonds (CARRÃO-PANIZZI, KWANYEN, ERHAN, LOPES, 2008). The two globulins show considerable differences in key functional properties, include gel-making ability, thermal stability and emulsifying capacity. (RENKEMA; KNABBEN; VLIET, 2011). In general, the $11 \mathrm{~S}$ protein has a better gel formation ability than the $7 \mathrm{~S}$ globulin.

On the other hand, the $7 \mathrm{~S}$ protein has a greater emulsifying capacity and emulsion stability than 11S globulin (POYSA, WOODROW, YU, 2005).

Studies on characterization and functional properties of the proteins glycinin and $\beta$-conglycinin in different soybean cultivars were carried out (MOLINA; PAPADOULOS; LEDWARD, 2001, RIBLETT et al., 2001, KHATIB et al., 2002, CARRÃO-PANIZZI et al., 2008). Both fractions are also capable of stimulating activity receptor for low density cholesterol (LDL), (ANTHONY, 2000; ERDMAN, 2000). This study evaluated the effects of genetic and environmental variation on levels of $\beta$-conglycinin and glycinin in twenty soybean varieties that were planted simultaneously in two different locations. These commercial cultivars were produced by Embrapa Soybean, and are recommended for sowings in Southern region of Brazil. Among the cultivars BRS 213 and BRS 257 do not present the lipoxygenases L1, L2 and L3, while BRS 242 RR, BRS 244 RR, BRS 245 RR, BRS 246RR, BRS 255 and BRS 256 RR RR are genetically modified. Studies reveal variations in protein and subunits in cultivars with high levels of $7 \mathrm{~S}$ and 11S (TAKAHASHI et al., 2001). The effects of environment on protein fractions were reported by Murphy and Ressureccion in 1984, and interaction between genotype and environment for the ratios of $11 \mathrm{~S} / 7 \mathrm{~S}$ proteins was also recorded by Helms et al. (1998) Therefore the content of these protein fractions were evaluated in 20 cultivars sowed in the region of Londrina $\left(23^{\circ} 11^{\prime} \mathrm{S}\right.$, altitude $630 \mathrm{~m}$ ) and Ponta Grossa (25 $09^{\circ} \mathrm{S}$ and 884 meters altitude)

\section{Materials and Methods}

To quantify the storage proteins glycinin (11S) and $\beta$-conglycinin (7S), these protein fractions were separated by discontinuous electrophoresis in polyacrylamide gel in denaturing conditions (SDSPAGE), according to the methodology proposed by Laemmli (1970) photo documented and quantified. The assays were carried out in triplicate, and approximately $10 \mathrm{mg}$ of each sample were placed in tubes of $1.5 \mathrm{ml}$ and added $1.0 \mathrm{~mL}$ of extraction buffer (sodium phosphate buffer $0.05 \mathrm{M}, \mathrm{pH} \mathrm{7,}$ $6,0.4 \mathrm{M} \mathrm{NaCl}$; $\beta$-mercaptoethanol $0.28 \%$. The tubes were maintained in the ultrasonic bath for 45 minutes, after that they were centrifuged for 15 $\min$ at $13,400 \mathrm{X} \mathrm{g}$ in a microcentrifuge, Eppendorf $34,15 \mathrm{c}$. The supernatant, $60 \mu \mathrm{L}$ were removed and 
added to another tube containing $30 \mathrm{~mL}$ of sample buffer $(0.1875$ M TRIS, $6.9 \%$ SDS, $30 \%$ glycerol, $\mathrm{pH} 6.8,20 \mathrm{~mL}$ of bromophenol blue dye, $0.05 \mathrm{~mL}$ of $20 \%$ and $\beta$-mercaptoethanol. The tubes were placed in a water bath at $100^{\circ} \mathrm{C}$ for 5 minutes and applied $25 \mathrm{~mL}$ of solution in $13.5 \%$ polyacrylamide gel. The electrophoretic separation was conducted at 40 volts until the dye band reached the surface of the separating gel $(\sim 1.0 \mathrm{~h})$; the voltage was increased to 80 volts and remained to the end of the separation $(\sim 5 \mathrm{~h})$, which was determined as at the $30 \mathrm{~min}$ after the dye reach the gel bottom. After separation, gels were removed from the card and placed in staining solution (1.5 g Coomassie Brilliant Blue G, $90 \mathrm{ml}$ of acetic acid, $450 \mathrm{~mL}$ of methanol and $460 \mathrm{~mL}$ of water) for $12 \mathrm{~h}$, and bleach in a solution of $75 \mathrm{~mL}$ of acetic acid, $250 \mathrm{~mL}$ of methanol and $675 \mathrm{~mL}$ of water for $24 \mathrm{~h}$. After bleach gels,, were stored in 10\% glycerol solution until photo-documentation, which was used for the L-PIX (Locus Biotechnology, São Paulo, Brazil). After being photographed the gels were quantified using Image Quant TL software, v8.0 (GE Healthcare, São Paulo, Brazil), resulting in areas corresponding to each subunit of interest. The subunits of storage proteins were identified based on electrophoretic mobility contained in papers published in the literature (FONTES et al., 1984; YAKLICH, 2001). To convert the area of each subunit into the amount of protein (mg) it was added to each gel $3 \mathrm{~g}$ protein standard bovine serum albumin (BSA). The concentration of $7 \mathrm{~S}$ was obtained by adding the amounts of subunits $\alpha^{\prime}, \alpha$ and $\beta$ (Figure 1). The content of 11S subunits was the total A3, and the basic A1aA1bA2A4 (Figure 1). Thus we obtained there a relationship $11 \mathrm{~S} / 7 \mathrm{~S}$. Statistical analyzes were performed by using ANOVA and means were compared by Tukey Test ( $5 \%$ probability). $t$

Figure 1. Electrophoretic patterns obtained by SDS-PAGE of protein extracts of the samples BRS 245 RR (1, 2 and 3), BRS 246 RR (5, 6 and 7), BRS 255 RR (8, 9 and 10), BRS 256 RR (11, 12 and 13) grown in Ponta Grossa-PR. The default (4) containing $3 \mathrm{mg}$ of protein bovine serum albumin. The identification of the subunits was based on literature reports (YAKLICH, 2001).

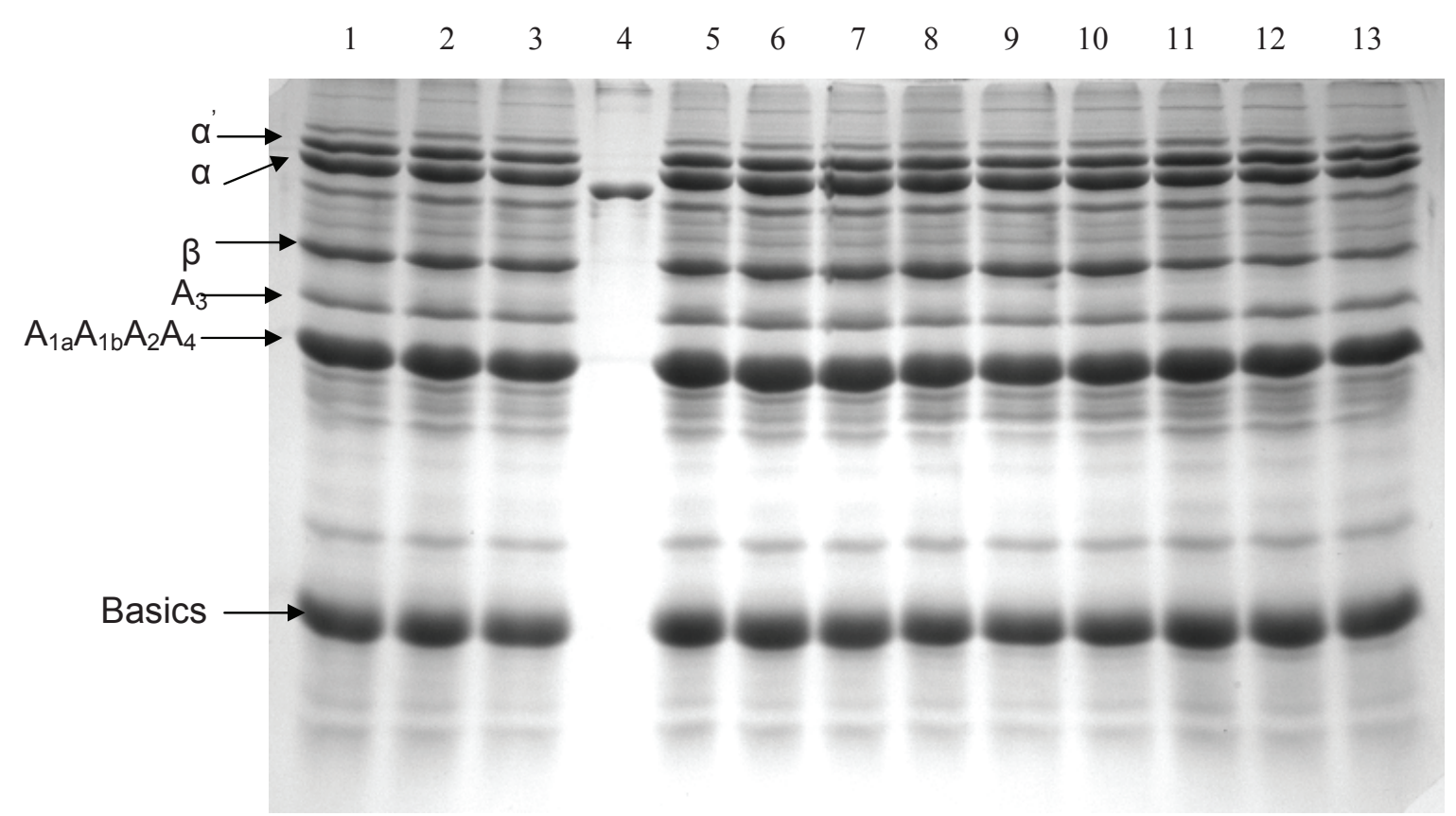

Source: Elaboration of the authors. 


\section{Results and Discussion}

The relative amounts of the proteins fractions7S and $11 \mathrm{~S}$ in soybean cultivars sowed in Londrina and Ponta Gross are presented in Tables 1 and 2, respectively. A variation for the $11 \mathrm{~S} / 7 \mathrm{~S}$ ratios were observed between locations and also among cultivars. The $11 \mathrm{~S}$ protein have high content of sulfur amino acids than $7 \mathrm{~S}$ subunit so the higher $11 \mathrm{~S} / 7 \mathrm{~S}$ ratio the better nutritional value and the functionality (JI, CAI; CHANG, 1999). An small variability was observed for the mean ratios of $11 \mathrm{~S} / 7 \mathrm{~S}$ among conventional cultivars for both locations 1.65 for Londrina and 1.67 for Ponta Grossa). Transgenic varieties in Londrina presented higher values for $11 \mathrm{~S} / 7 \mathrm{~S}$ ratio (1.95). The same tendency was observed in Ponta Grossa, conventional cultivars shown a average of 1.67 and transgenic cultivars presented an average of $1.7411 \mathrm{~S} / 7 \mathrm{~S}$ ration . Comparing data from Londrina and Ponta Grossa it was observed larger $11 \mathrm{~S} / 7 \mathrm{~S}$ rations for transgenic varieties in both locations 1.95 to 1.74 respectively. Showing that variations on climate or location had affect these protein fractions. Carrão Panizzi et al. (2008), investigated the genetic variation and environment effects for different Brazilian cultivars and found higher values than those observed in our study, which confirms variability due to different cultivars, soybean season and locations. They also worked with a larger number of soybean genotypes and observed a range of 2.76 for cultivar BRS 169-Bacuri to 1.18 ratio of $11 \mathrm{~S} / 7 \mathrm{~S}$ for cultivar BR8 Pelotas. Differences among cultivars sowed in Londrina, showed that cultivar BRS 262 presented the lowest content of beta-conglycinin (7S) 5.86, while BRS 233 presented the highest value (10.44) (Table 1). Moraes et al. (2006), analyzing three soybean lines with high protein content $(43.17 \%$ on average), found values for the relationship of these varieties $11 \mathrm{~S} / 7 \mathrm{~S}$ UFVTN $105,1.17 ; 1.85$ and 1.87 for isoline 1 and 2. Mujoo, Trinh and $\mathrm{Ng}$ (2003) studied seven soybean varieties and found values for the ratio $11 \mathrm{~S} / 7 \mathrm{~S}$ between 1.58 and 2.06 , values compatible with the varieties in this work. The same conventional cultivars when sowed in Ponta Grossa presented 8.49 and 8.97 for $7 \mathrm{~S}$ protein fraction, considering the range of 7.28 (BRS 184) to 10.99 (BRS 258) (Table 2). For glycinin (11S) protein fraction the highest value observed in Londrina was for cultivar BRS 184 (17.25) and lowest for BRS 259 (11.44) (Table 1). In Ponta Grossa the same cultivars showed 16.03 and 14.14 11S protein fractions, respectively, considering the range for this compound was 114.4 to 16.45 among conventional cultivars (Table 2).

\section{Statistical Procedure}

Multivariate analysis can summarize the variability of a complex data set and present it in a more interpretable form. For this reason, Principal Component Analysis of the physicochemical parameters was carried out. The results of this work were confirmed by means of multivariate techniques - PCA which was also applied, to verify the discrimination capacity of the variables of the local groupings (MORRISON. 1990) 


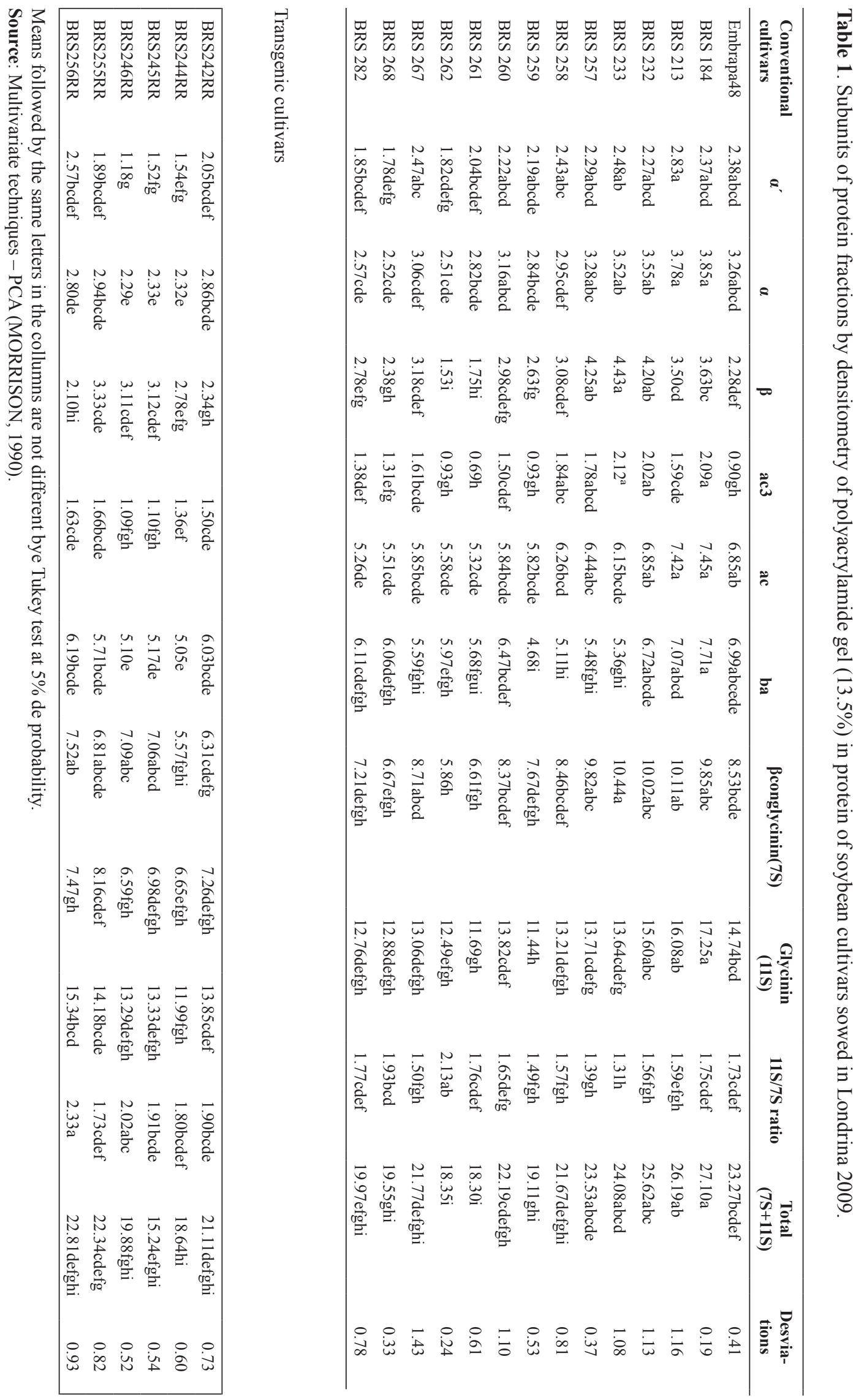




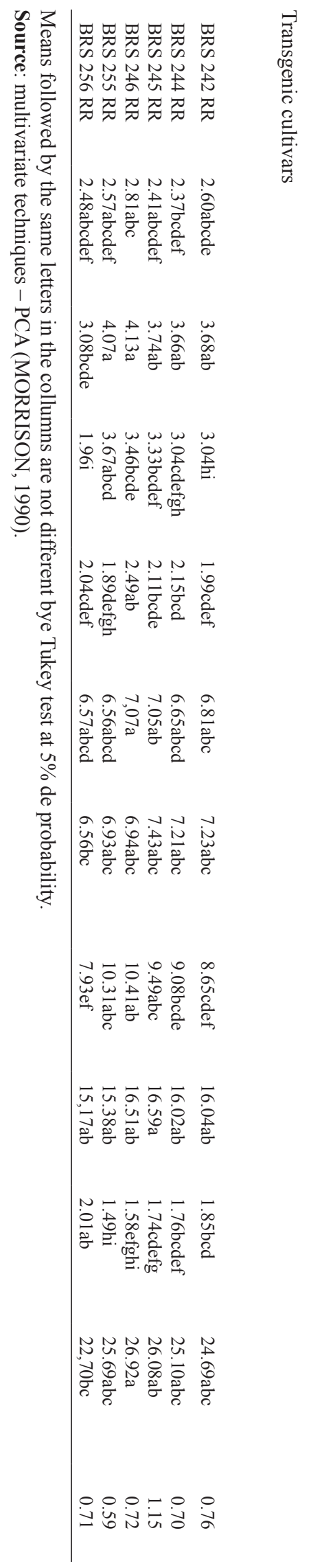

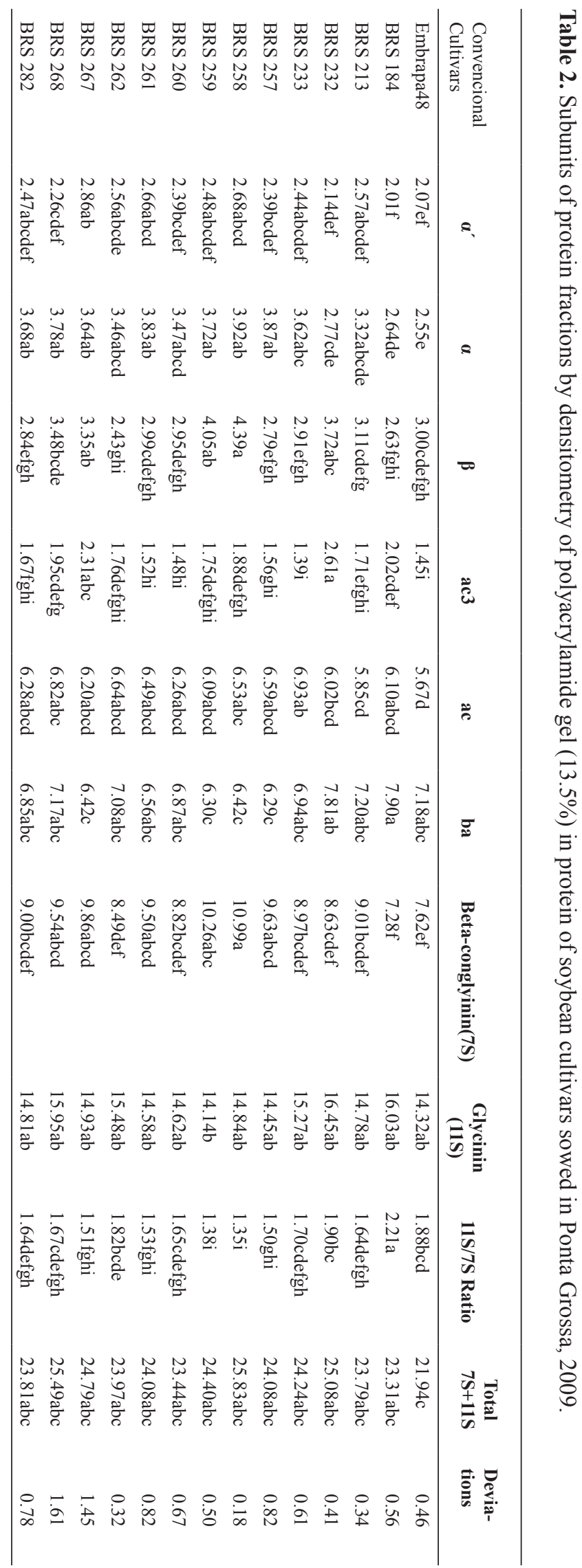


Figure 2. Shows the functional relationship and closeness among the variables (protein fraction).

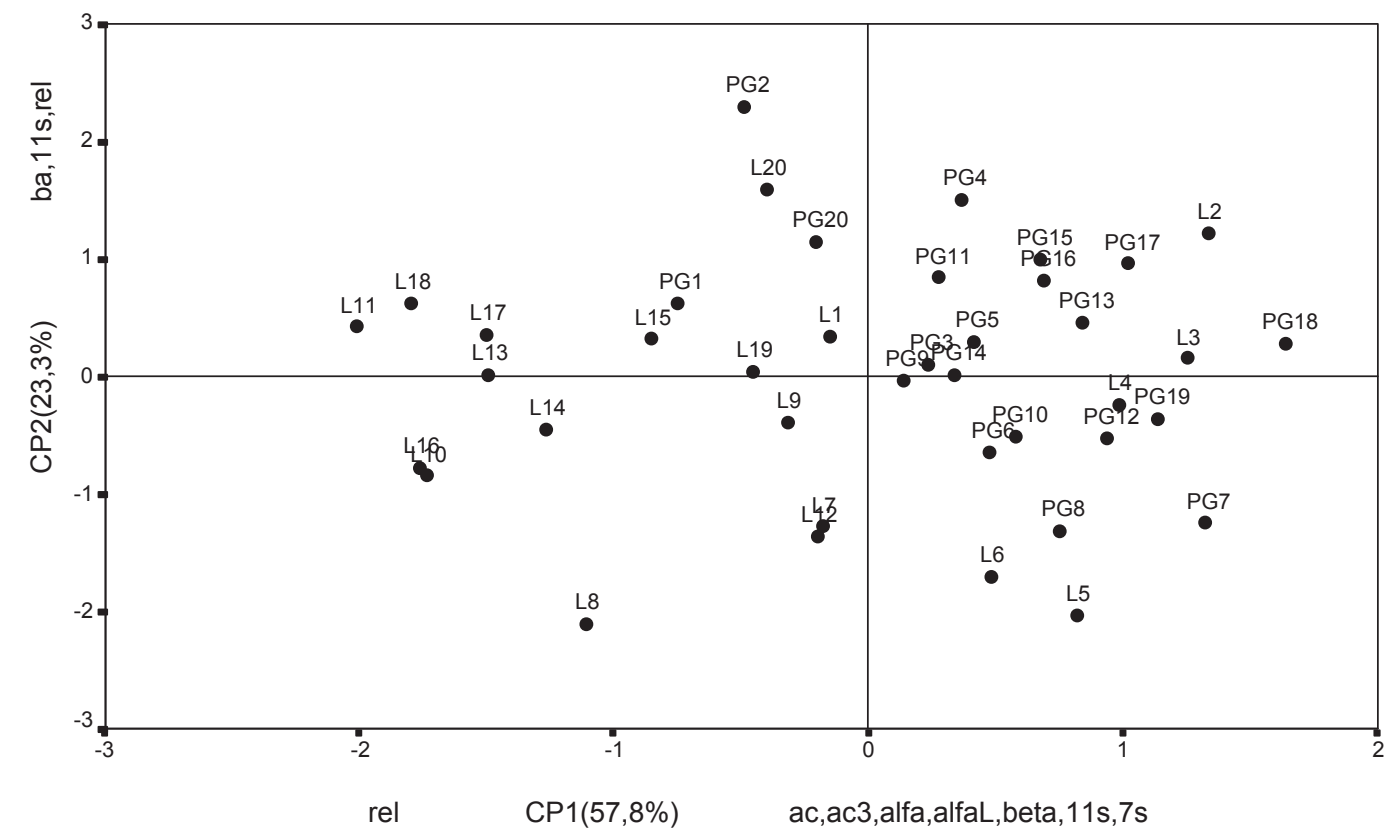

Source: Elaboration of the authors, using program R, Springer, 2011, XII, 306 p.

Figure 1. Samples of soybeab cultivars sowed in Londrina $=$ letter L and in Ponta Grossa $=$ PG.

Samples 1 and 21 - Embrapa 48; 2 and $22-$ BRS 184; 3 and 23-BRS 213, 4 and 24--BRS 232; 5 and 25- BRS 233; 6 and $26-$ BRS 257; 7 and 27-BRS 258, 8 and 28 - BRS 259; 9 and 29 - BRS 260, 10 and 30-BRS261, 11 and $31-$ BRS 262, 12 and $32-$ BRS 267; 13 and33-BRS 268; 14 and 34 - BRS 282; 15 and 35-BRS 242RR; 16 and 36-BRS 244RR; 17 and 37 - BRS 245RR; 18 and38-BRS 246RR; 19 and 39 - BRS 255RR; 20 and 40 - BRS 2456RR.

This two-dimensional representation provides a scattering of samples, according to their relative position in the plane defined by principal component analysis 1 (PC1) and principal component analysis 2 (PC2) from multivariate statistical analysis. The first component PC1 (horizontal axis), explains
$57,8 \%$ of the variance and the second component PC2 (longitudinal axis) is associated with $23,3 \%$ of the protein fractions. The majority of samples from Ponta Grossa were more influenced by the fractions ac3, alpha, alpha', beta ad 11S, while samples from Londrina had a greater influence of basic subunit and $11 \mathrm{~S} / 7 \mathrm{~S}$ relation.

Figure 2. shows similarity diagram of the samples by the Ward's method of highlighting the groups that are represented in Fig. 1.

The cultivars from Londrina, BRS 261, BRS 262, BRS 268, BRS 282, BRS 244RR and BRS 246RR. Showed higher influence of subunit basic and also for total 11S. Variables ac, ac3, alpha' alpha beta and the most part $11 \mathrm{~S}$ had lager influence for Ponta Grossa cultivars. 
Figure 3. Dendogram for the 20 samples analyzed.

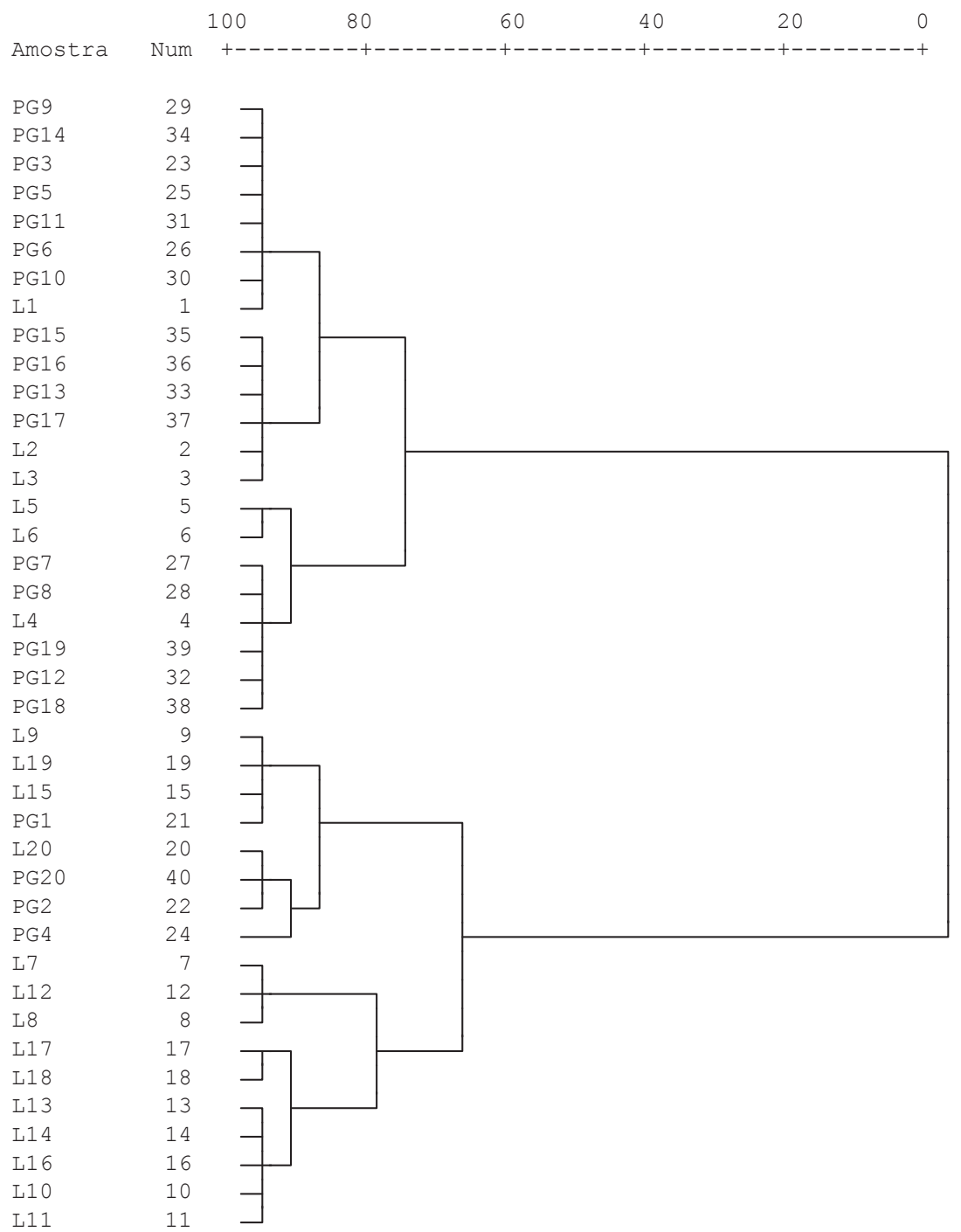

Source: Elaboration of the authors, using program R, Springer, 2011, XII, 306 p.

\section{Conclusions}

Genetic improvements in search of new varieties allow change in $11 \mathrm{~S} / 7 \mathrm{~S}$ ratios. Theses fractions differ in amino acid profiles and functional properties. $7 \mathrm{~S}$ proteins present reducing power of serum cholesterol levels. Thus, a breeding to produce changes in $11 \mathrm{~S} / 7 \mathrm{~S}$ ratios may alter functional properties and benefits to human health.
The conventional cultivars of Londrina and Ponta Grossa were not different $11 \mathrm{~S} / 7 \mathrm{~S}$ ratios (1,66 for Londrina and 1,67 for Ponta Grossa). The transgenic cultivars show media 1,90 in Londrina and 1,73 for Ponta Grossa, both with highest than conventional cultivars. The concentration affects the lease for such components, but more intensely in transgenic varieties. 


\section{References}

ANUÁRIO DA AGRICULTURA BRASILEIRA AGRIANUAL. Agrafnp. FNP/Consultoria e Comércio, 2010. p. 453-483.

ANTHONY, M. Soy and cardiovascular disease: cholesterol lowering and beyond. The American Society for Nutritional Sciences, 9650 Rockville Pike, Bethesda, v. 130, n. 3, p. 6625-6635, 2000.

BOCARD., D.; GILLET, F.; LEGENDRE, P. Numerical Ecology with R. Springer, XII, 2011. 306 p.

BITTERCOURT, A. L.; SOARES, M. F. M.; PIRES, R. R.; HONMOTO, S.; TANAKA, M. K.; JACOB, C. M. A.; ABDALLA, D. S. Immunogenicity and allergenicity of 2S, 7S and $11 \mathrm{~S}$ soy protein fractions. Revista Brasileira de Ciências Farmacêuticas, USP, v. 43, n. 4, p. 597-606, out./dez. 2007.

CARRÃO-PANIZZI, M. C.; KWANYUEN, P.; ERHAN, Z.; LOPES, I. O. N. Genetic variation and environmental effects on beta-conglycinin and glycinin content in Brazilian soybean cultivars. Pesquisa Agropecuária Brasileira, Brasília, v. 43, n. 9, p. 1105-1114, 2008.

ERDMAN, J. W. Soy protein and cardiovascular disease: a statement for healthcare professionals from de nutrition committee of de AHA (American Heart Association). Circulation, New Orleans, v. 102, n. 102, p. 2555-2559, 2000.

FONTES, E. P. B.; MOREIRA, M. A.; DAVIES, C. S.; NIELSEN, N. C. Urea elicited in relative electrophoretic mobility of certain glycinin and $\beta$-conglycinin subunits. Plant Physiology, Illinois, v. 76, n. 3, p. 840-842, 1984.

HELMS, T. C.; CAI, T. D.; CHANG, K. C.; ENZ, J. W. Tofu characteristics influenced by soybean crop year and location. Crop Science Society of America, North Dakota State University, v. 43, n. 3, p. 511-514, 2003.

JI, M. P.; CAI, T. D.; CHANG, K. C. Tofu yield and textural properties from three soybean cultivars as Affected by ratios of $7 \mathrm{~S}$ and $11 \mathrm{~S}$ proteins. Journal of Food Science, Chicago, v. 64, n. 5, p. 763-767, 1999.

KHATIB, K. A.; HERALD, T. J.; ARAMOUNI, F. M.; MAcRITHIE, F.; SCHAPAUGH, W. T. Characterization an functional properties of soy $\beta$-conglycinin and glicinin of selected genotypes. Journal of Food Science, Chicago, v. 67, n. 4 , p. 2923-2929, 2002.

KITAMURA, K. Genetic improvement of nutritional and food processing quality in soybean. Japan Agricultural Research Quarterly, v. 29, p. 1-8, 1995.
LAEMMLI, U. K. Cleavage on structural proteins during the assembly of the head of bacteriophage T4. Nature, London, v. 227, p. 680-685, aug. 1970.

MOLINA, E.; PAPADOULOS, A.; LEDWARD, D. A. Emulsifying properties of high pressure treated soy protein isolate and $7 \mathrm{~S}$ and $11 \mathrm{~S}$ globunins. Food Hydrocolloinds, University of Reading, Whiteknights, UK, v. 15, n. 3, p. 263-269, 2001.

MORAES, R. M. A.; JOSÉ, I. C.; RAMOS, F. G.; BARROS, E. G.; MOREIRA, M. A. Caracterização bioquímica de linhagens de soja com alto teor de proteína. Pesquisa Agropecuária Brasileira, Brasília, v. 41, n. 5, p. 725-729, 2006.

MORRISON, D. F. Multivariate statistical methods. 3. ed. Boca Raton: CRC Press, 1990.

MUJOO, R.; TRINH, D. T.; NG, P. K. W. Characterization of storage proteins in different soybean varieties and their relationship to tofu yield and texture. Food Chemistry, v. 82 , n. 2, p. 265-273, 2003.

MURPHY, P. A.; RESSURCCION, A. P. Varietal and environmental differences in soybean glycinin and betaconclycinin content. Journal of Agricultural and Food Chemistry, Washington, DC, v. 32, p. 911-915, 1984.

NIELSEN, N. C.; JUNG, R.; NAM, Y. W.; BEAMAN, T. W.; OLIVEIRA, L. O.; BASSUNER, R. Synthesis and assembly of $11 \mathrm{~S}$ globulins. Journal of Plant Physiology, Stuttgart, v. 145, n. 5-6, p.641-647, 1995.

OGAWA, T.; TAYAMA, E.; KITAMURA, K.; KAIZUMA, N. Genetic improvement of seed storage proteins using three variant alleles of $7 \mathrm{~S}$ globulin subnits in soybean (Glycine max L.) Japanese Journal of Breeding, Japan, v. 39, p. 137-147, 1989.

PIPOLO, A. E. Influência da temperatura sobre as concentrações de proteína e óleo em sementes de soja (Glycine $\max$ (L.) Merrill). 2002. Tese (Doutorado em Agronomia) - Universidade Estadual de São Paulo, Piracicaba.

POYSA, V.; WOODROW, L.; YU, K. Effect of soy protein subunit composition on tofu quality. Food Research International, Canada, v. 39, n. 3, p. 309-317, 2006.

RENKEMA, J. M. S.; KNABBEN, J. H. M.; VLIET, T. van. Gel formation by $\beta$-conglycinin and glycinin and their mixtures. Food Hydrocolloids, Lancaster, v. 15, n. 4-6, p. 404-414, 2001. 
RIBLETT, A. L.; HERALD, T. J.; SCHIMIDT, K. A.; TILLEU, K. A. Characterization of $\beta$-conglycinin and glycinin soy protein fractions from fou selected soybean genotypes. Journal of Agricultural and Food Chemistry, Washington, v. 49, n. 10, p. 4983-4989, 2001.
TAKAHASHI, P. E.; HERMODSON, M. A.; NIELSEN, N. C. Suppression of soybean $\beta$-conglycinin genes by a dominant gene, Scg-1. Theor Appl Genet, SpringerVerlag, v. 103, n. 8, p. 1266-1272, 2001.

YAKLICH, R. W. $\beta$-Conglycinin and glycinin in high protein soybean seeds. Journal of Agricultural and Food Chemistry, Washington, v. 49, n. 2, p. 729-735, 2001. 